\title{
IMPROVING UTILIZATION OF OLIVE CAKE SILAGE BY TREATING WITH FIBROLYTIC ENZYMES ON DIGESTIBILITY AND GAS PRODUCTION IN THE RUMEN
}

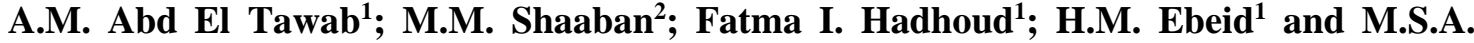 \\ Khattab $^{1}$
}

${ }^{1}$ Dairy Sciences Department, National Research Centre, 33 Bohouth St., Dokki, Giza, Egypt.

${ }^{2}$ Biological Applications Department, Nuclear Research Center, Atomic Energy Authority, Inshas, Cairo, Egypt.

(Received 10/8/2018, accepted 30/8/2018)

SUMMARY

I $n$ vitro study was carried out to determine the effect of replacing clover hay with olive cake silage with or without fibrolytic enzymes on rumen fermentation and gas production and dry matter disappearance. The experimental diets consist of 50: 50 concentrate: roughage ratio (on DM basis); the experiments divided into four groups, the first group diet was 50\% concentrate feed mixture (CFM): $50 \%$ clover hay (control). The second group diets were replaced clover hay by olive cake by 25,50 and $75 \%$ for $\mathrm{T} 1, \mathrm{~T} 2$ and $\mathrm{T} 3$, respectively. The third group diets were replaced clover hay by olive cake silage by 25,50 and $75 \%$ for T4, T5 and T6, respectively. The fourth group diets were replaced clover hay by treated olive cake silage with fibrolytic enzymes by 25,50 and $75 \%$ for T7, T8 and T9, respectively. The results of ensiling olive cake showed that treated olive cake silage was recorded the lower values in $\mathrm{pH}$ and NH3-N compared with untreated silage. Results showed a significant decrease in gas production and relative gas production to DM and fiber fractions in all treatments compared with control. DM disappearance showed that T1, T4, T7 and T8 recorded a significant increase compared with control. The current findings reflects a potential possibility of replacing clover hay with olive cake silage especially treated with fibrolytic enzymes.

Keywords: In vitro, ruminants, fibrolytic enzyme, olive cake, clover hay and digestibility.

\section{INTRODUCTION}

Olive cake is one of agro-industrial by-products which potentially used as feedstuff for ruminant animal. Olive cake incorporation into animal's diets lowering the ration cost (Molina-Alcaide and Yãnez-Ruiz, 2008). Olive cake shows a different range in chemical composition according to different factors (such as olive species and method of extraction) (Abbeddou et al., 2011). Low digestibility of olive cake might be due to high contents of fiber and presence of anti-nutritional factors (tannins) (Molina-Alcaide and Nefzaoui, 1996; Al-Masri and Guenther, 1995 and Abd El Tawab et al., 2015 and 2016). Many studies were investigated inclusion of olive cake in ruminant diets either crude, chemically or biologically treated. Common investigated chemical treatments were ammonia and sodium hydroxide (Molina Alcaide and Nefzaoui, 1996 and Awawdeh and Obeidat, 2013) while, the most common biological method for improving olive cake characteristics was ensiling either with additives or without (Al Jassim et al., 1997; Hadjipanayiotou, 1994, 1999). Different studies were suggested that fibrolytic enzymes have a positive effect on nutrients digestibility and animal performance (Feng et al., 1996 and Dong et al., 1999). Moreover, fibrolytic enzymes can be effective additive with agro-industrial byproduct to improve nutritive value of fiber rich diets (Awawdeh and Obeidat, 2011; Salihu et al., 2015 and Abd El Tawab et al., 2016). Giraldo et al. (2004) determined that a pre-ingestive enzyme-feed interaction is substantial for enhancing effects on ruminal digestion. The aim of this study was to investigate the effect of ensiling olive cake treated with or without fibrolytic enzymes on rumen fermentation and gas production, dry matter, organic matter and fiber degradation. 


\section{MATERIALS AND METHODS}

\section{Enzyme sources:}

Fibrolytic enzymes produced from anaerobic bacteria (Clostridium butyricum) at Dairy Science Department, National Research Centre, Dokki, Giza, Egypt. Each gram of enzymes contains 5000 IU/g of cellulase (Khattab et al., 2017).

\section{Collection and ensiling of crude olive cake:}

Fresh olive cake (Olea europaea) was collected from Al-Salhiya Agricultural Company, Al-Sharqia, Egypt. Olive cake moisture content was adjusted to $65-70 \%$ before ensiling, treating silage was prepared by spraying fresh olive cake with four liter of enzyme solution per ton DM of olive cake (treated silage), or without crude enzyme, which sprayed with four liter of water (untreated silage). The material was ensiled in plastic bags for two months before feeding to the ewes. Chemical compositions of olive cake silage were determined as shown in Table (2).

\section{Diets and in-vitro procedures:}

In-vitro incubation was carried out as described by Khattab et al. (2016). The experimental diets consist of 50:50 concentrate: roughage ratio (on DM basis); the experiment diets divided into four main groups, the first group diet was 50\% CFM, 50\% clover hay (control). The second group diet was $50 \%$ CFM, replaced clover hay by olive cake by 25,50 , and $75 \%$ for T1, T2 and T3, respectively. The third group diet was 50\% CFM, replaced clover hay by olive cake silage by 25,50 and $75 \%$ for T4, T5 and T6, respectively. The fourth group diet was 50\% CFM, replaced clover hay by treated olive cake silage with fibrolytic enzymes by 25,50 and $75 \%$ for T7, T8 and T9, respectively (Table 1).

Table (1): Formula of the experimental rations (\%).

\begin{tabular}{|c|c|c|c|c|c|c|}
\hline Item & & $\begin{array}{c}\text { Concentrate feed } \\
\text { mixture (CFM) }\end{array}$ & $\begin{array}{c}\text { Clover } \\
\text { hay }\end{array}$ & $\begin{array}{c}\text { Crude olive } \\
\text { cake }\end{array}$ & $\begin{array}{c}\text { Untreated olive } \\
\text { cake silage }\end{array}$ & $\begin{array}{l}\text { Treated olive } \\
\text { cake silage }\end{array}$ \\
\hline Control & & 50 & 50 & --- & --- & --- \\
\hline $\begin{array}{l}\text { Crude } \\
\text { olive cake }\end{array}$ & $\begin{array}{l}\mathrm{T} 1 \\
\mathrm{~T} 2 \\
\mathrm{~T} 3\end{array}$ & $\begin{array}{l}50 \\
50 \\
50\end{array}$ & $\begin{array}{l}37.5 \\
25.0 \\
12.5\end{array}$ & $\begin{array}{l}12.5 \\
25.0 \\
37.5\end{array}$ & $\begin{array}{l}--- \\
--- \\
---\end{array}$ & $\begin{array}{l}--- \\
--- \\
---\end{array}$ \\
\hline $\begin{array}{l}\text { Untreated } \\
\text { olive cake } \\
\text { silage }\end{array}$ & $\begin{array}{l}\text { T4 } \\
\text { T5 } \\
\text { T6 }\end{array}$ & $\begin{array}{l}50 \\
50 \\
50\end{array}$ & $\begin{array}{l}37.5 \\
25.0 \\
12.5\end{array}$ & $\begin{array}{l}--- \\
--- \\
---\end{array}$ & $\begin{array}{l}12.5 \\
25.0 \\
37.5\end{array}$ & $\begin{array}{l}--- \\
--- \\
---\end{array}$ \\
\hline $\begin{array}{l}\text { Treated } \\
\text { olive cake } \\
\text { silage }\end{array}$ & $\begin{array}{l}\text { T7 } \\
\text { T8 } \\
\text { T9 }\end{array}$ & $\begin{array}{l}50 \\
50 \\
50\end{array}$ & $\begin{array}{l}37.5 \\
25.0 \\
12.5\end{array}$ & $\begin{array}{l}--- \\
--- \\
---\end{array}$ & $\begin{array}{l}--- \\
--- \\
---\end{array}$ & $\begin{array}{l}12.5 \\
25.0 \\
37.5\end{array}$ \\
\hline
\end{tabular}

The chemical composition of feedstuff ingredients and experimental rations are showed in Table (2).

Rumen fluid was collected from 3 ruminal cannulated Holstein dairy cows (mean weight $680 \pm 30$ $\mathrm{kg}$ ). The collected rumen fluid (before morning feeding) was mixed and squeezed through a 4-layers cheesecloth under continuous flushing with $\mathrm{CO}_{2}$ and immediately transported to laboratory at $39^{\circ} \mathrm{C}$, where it was used as a source of inoculum. Each treatment was tested in eight replicates (the experiment was repeated twice) accompanied by blank vessels (no substrate). $400 \mathrm{mg}$ of milled substrate was added to the incubation vessels of $100 \mathrm{ml}$ capacity. Each vessel was filled with $40 \mathrm{ml}$ of the incubation medium

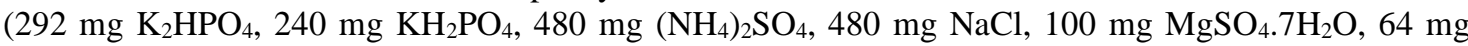


$\mathrm{CaCl}_{2} .2 \mathrm{H}_{2} \mathrm{O}, 4 \mathrm{mg} \mathrm{Na} \mathrm{CO}_{3}$ and $600 \mathrm{mg}$ cysteine hydrochloride) per 1 liter of double distilled water $\left(\mathrm{ddH}_{2} \mathrm{O}\right)$ and dispensed anaerobically in the $1: 4(\mathrm{v} / \mathrm{v})$ ratio. Then the treatments were incubated at $39^{\circ} \mathrm{C}$ for $24 \mathrm{~h}$. The average of the volume of gas produced from the blanks was deducted from the volume of gas produced per sample. After $24 \mathrm{~h}$ digestion, the samples were transferred into test tubes and centrifuge for $1 \mathrm{~h}$ in order to obtain the residues which were then filtered and the residues dried at $65^{\circ} \mathrm{C}$ for $24 \mathrm{~h}$. The dry residues were weighed and digestibility calculated using the equation as follows:

$$
\operatorname{IVDMD}(\%)=[(\text { initial DM input }- \text { DM residue }- \text { blank }) / \text { initial DM input }] * 100
$$

\section{Samples analysis:}

Samples of rumen fluid samples were analyzed for $\mathrm{pH}$ and $\mathrm{NH}_{3}-\mathrm{N}$. Substrates and substrate residues after $48 \mathrm{~h}$ of incubation were dried at $70^{\circ} \mathrm{C}$ and analyzed for the amount of DM (DM digestibility) according to AOAC (1995). The NH3-N concentration was determined as described by Khattab et al. (2016). Neutral detergent fiber (NDF) and acid detergent fiber (ADF) were analyzed by Ankom 200 Fiber Analyzer (Ankom Technology Corporation, Fairport, NY) according to Van Soest et al. (1991).

\section{Statistical analysis:}

Data were statistically analyzed using GLM procedure of SAS software (Version 9.2). Significant differences between means of treatments were carried out by the Duncan's test, and the significance threshold was set at $\mathrm{P}<0.05$.

\section{RESULTS AND DISCUSSION}

\section{Silage quality:}

Data in Table (2) showed the chemical composition of different ration ingredients. Results showed that treating olive cake silage with fibrolytic enzymes reduced NDF and hemicellulose and NH3-N concentration as compared with untreated silage. Adding fibrolytic enzymes enhance degradation of plant cell wall and yielding soluble sugars which could be fermented by lactic acid bacteria to consequently lowering the silage $\mathrm{pH}$ (Kung, 2010). Reduction in $\mathrm{NH}_{3}-\mathrm{N}$ concentration related to decrease deamination and degradation of silage proteins content by lower $\mathrm{pH}$ value (Kung, 2010).

Table (2): Chemical analysis of feed ingredients (on DM basis \%).

\begin{tabular}{|c|c|c|c|c|c|c|c|c|c|c|}
\hline Item & DM & $\mathrm{OM}$ & $\mathrm{CP}$ & $\mathrm{EE}$ & $\mathrm{NDF}$ & $\mathrm{ADF}$ & Hemicellulose & Ash & $\mathrm{pH}$ & $\begin{array}{c}\mathrm{NH}_{3}-\mathrm{N} \\
(\mathrm{mM})\end{array}$ \\
\hline CFM & 93.09 & 93.98 & 12.73 & 6.28 & 49.98 & 18.09 & 31.9 & 6.02 & --- & --- \\
\hline Clover hay & 93.86 & 88.31 & 11.97 & 6.10 & 43.49 & 33.06 & 10.4 & 11.69 & --- & --- \\
\hline Crude olive cake & 55.23 & 94.71 & 6.17 & 12.76 & 64.84 & 55.37 & 9.5 & 5.29 & --- & --- \\
\hline Untreated olive cake silage & 45.06 & 97.37 & 5.16 & 14.79 & 71.04 & 54.87 & 16.2 & 2.63 & 4.10 & 3.50 \\
\hline Treated olive cake silage & 46.34 & 96.78 & 5.38 & 12.36 & 66.84 & 58.53 & 8.3 & 3.22 & 4.07 & 2.61 \\
\hline \multicolumn{11}{|c|}{ Ration chemical composition, \% (DM) } \\
\hline Control & 93.47 & 91.15 & 12.35 & 6.19 & 46.74 & 25.58 & 21.15 & 8.85 & --- & --- \\
\hline $\mathrm{T} 1$ & 88.65 & 91.94 & 11.63 & 7.02 & 49.40 & 28.36 & 21.04 & 8.06 & --- & --- \\
\hline $\mathrm{T} 2$ & 83.82 & 92.74 & 10.90 & 7.85 & 52.07 & 31.15 & 20.93 & 7.26 & --- & --- \\
\hline $\mathrm{T} 3$ & 78.99 & 93.54 & 10.17 & 8.69 & 54.74 & 33.94 & 20.81 & 6.46 & --- & --- \\
\hline $\mathrm{T} 4$ & 87.37 & 92.28 & 11.50 & 7.27 & 50.18 & 28.30 & 21.88 & 7.72 & --- & --- \\
\hline $\mathrm{T} 5$ & 81.27 & 93.41 & 10.65 & 8.36 & 53.62 & 31.03 & 22.60 & 6.59 & --- & --- \\
\hline T6 & 75.17 & 94.54 & 9.80 & 9.45 & 57.07 & 33.75 & 23.33 & 5.46 & --- & --- \\
\hline $\mathrm{T} 7$ & 87.53 & 92.20 & 11.53 & 6.97 & 49.65 & 28.76 & 20.89 & 7.80 & --- & --- \\
\hline T8 & 81.59 & 93.26 & 10.70 & 7.75 & 52.57 & 31.94 & 20.63 & 6.74 & --- & --- \\
\hline T9 & 75.65 & 94.32 & 9.88 & 8.53 & 55.49 & 35.13 & 20.36 & 5.68 & --- & --- \\
\hline
\end{tabular}

CFM: Concentrate feed mixer.

\section{Gas production:}

The effects of experimental diets on total gas production (TGP) are illustrated in Table (3). Control recorded the highest $(\mathrm{P}<0.05)$ value compared with other treatments, but $\mathrm{T} 1$ showed the lowest TGP 
$(\mathrm{P}<0.05)$. Whilst, the data showed no difference $(\mathrm{P}>0.05)$ between other treatments $\mathrm{T} 2$ to T9. Reduction of TGP reflect the effect of ensiling, anti-nutritional substances like tannins and lignin contents in diets contain olive cake which influence microbial proliferation in rumen (Al-Masri and Guenther, 1995, Al Jassim et al., 1997 and Hadjipanayiotou, 1994 and 1999). Also, the data were cleared the reduction $(\mathrm{P}<0.05)$ in relative gas production either per DM, NDF, ADF or hemicellulose from all treatments compared with control. It well knows that there is a negative relationship between gas production and cell wall content (NDF and ADF), which influence on microbial activity (De Boever et al., 2005 and Karabulut et al., 2007).

\section{Ruminal pH and ammonia concentrations:}

The effects of experimental diets on $\mathrm{pH}$ and ammonia concentration are listed in Table (4). Generally, all experimental treatments slightly lowered $\mathrm{pH}$ compared with control, the decrease of $\mathrm{pH}$ values might due to increase olive cake oil in rations which known to lack of fiber digestibility and decrease ruminal $\mathrm{pH}$ (Ørskov and Ryle, 1990). Also, tannins and lignin contents in diets contain olive cake influence microbial proliferation in rumen (Al-Masri and Guenther, 1995). The results showed that ammonia concentration recorded higher value for silage groups (T4:T9) compared with control. Minimal ammonia concentration may depend on the substrate availability (Erdman et al., 1986), or on the microbial species taking part in its degradation. These results were agreed with Sujani and Seresinhe (2015), who found that ruminal ammonia concentration, was higher in fibrolytic enzyme supplemented.

\section{Nutrients digestibility:}

The effect of experimental diets on in vitro nutrients digestibility is presented in Table (5). Replacements of clover hay with olive cake increased DM digestibility in all levels expect level 75\% (T3, T6 and T9) was decreased in all groups than control. Also, fourth group (T7 and T8) was showed higher value of DM digestibility than the second groups (T1 and T2) and the third groups (T4 and T5). However, the NDF digestibility was recorded the highest values $(\mathrm{P}<0.05)$ in $\mathrm{T} 9$ compared with other treatments. The results showed that ensiled olive cake with fibrolytic enzymes may be enhance the digestion and the utilization of dry matter and fiber and reduce DM losses (Muwalla et al., 2007, Kung, 2010 and Salihu et al., 2015). Bendaou (2003) found that the pre-degradation in cell walls by ensiling material by-product fermentation simplify microbial access in the rumen contents cell, which enhances the digestibility. Also, ADF digestibility was recorded higher values $(\mathrm{P}<0.05)$ in all levels $75 \%$ replacement clover hay with olive cake (T3, T6 and T9) compared with other treatments.

\section{CONCLUSION}

The present in vitro study showed that incorporation treated olive cake silage with fibrolytic enzymes in ruminants' diet had positive effect on dry matter digestibility and ammonia concentration at replacement levels 25 and 50\% of clover hay. Generally, replacement olive cake instead of clover hay had negative effect on gas production in ruminant's diets which enhance diet utilization. 
Table (3): Effect of experimental diets on gas production (GP).

\begin{tabular}{|c|c|c|c|c|c|c|c|c|c|c|c|}
\hline \multirow{2}{*}{ Item } & \multirow{2}{*}{ Control } & \multicolumn{3}{|c|}{ Crude olive cake } & \multicolumn{3}{|c|}{ Untreated olive cake silage } & \multicolumn{3}{|c|}{ Treated olive cake silage } & \multirow{2}{*}{$\pm \mathrm{SEM}$} \\
\hline & & $\mathrm{T} 1$ & $\mathrm{~T} 2$ & T3 & $\mathrm{T} 4$ & T5 & T6 & $\mathrm{T} 7$ & T8 & T9 & \\
\hline Total GP & $144.25^{\mathrm{a}}$ & $134.5^{\mathrm{c}}$ & $140.3^{\mathrm{b}}$ & $138.3^{\mathrm{b}}$ & $139.5^{\mathrm{b}}$ & $139^{\mathrm{b}}$ & $140.5^{\mathrm{b}}$ & $139.3^{\mathrm{b}}$ & $140.3^{\mathrm{b}}$ & $139.75^{\mathrm{b}}$ & 0.456 \\
\hline GP/gm DM & $356.8^{\mathrm{a}}$ & $331.5^{\mathrm{c}}$ & $342.3^{\mathrm{b}}$ & $343.5^{\mathrm{b}}$ & $343^{\mathrm{b}}$ & $343.8^{\mathrm{b}}$ & $348^{\mathrm{b}}$ & $343.8^{\mathrm{b}}$ & $346.7^{\mathrm{b}}$ & $346.3^{\mathrm{b}}$ & 1.217 \\
\hline $\mathrm{GP} / \mathrm{gm} \mathrm{NDF}$ & $763^{\mathrm{a}}$ & $671^{\mathrm{cd}}$ & $657.5^{\mathrm{d}}$ & $627.3^{\text {ef }}$ & $683.5^{\mathrm{bc}}$ & $641.3^{\mathrm{e}}$ & $610.3^{\mathrm{g}}$ & $692.3^{\mathrm{b}}$ & $659.3^{\mathrm{d}}$ & $624.3 \mathrm{f}^{\mathrm{g}}$ & 7.012 \\
\hline $\mathrm{GP} / \mathrm{gm} \mathrm{ADF}$ & $1686.3^{\mathrm{ab}}$ & $1575.8^{\mathrm{e}}$ & $1635^{\mathrm{d}}$ & $1649.8^{\mathrm{bcd}}$ & $1567.3^{\mathrm{e}}$ & $1522.3^{\mathrm{f}}$ & $1492.3^{\mathrm{f}}$ & $1644.8^{\mathrm{cd}}$ & $1680.7^{\mathrm{abc}}$ & $1701.3^{\mathrm{a}}$ & 11.651 \\
\hline GP/gm hemicellulose & $1394^{\mathrm{a}}$ & $1169^{c}$ & $1098.5^{\mathrm{d}}$ & $1011.8^{\mathrm{ef}}$ & $1212^{\mathrm{b}}$ & $1108.5^{\mathrm{d}}$ & $1031.5^{\mathrm{e}}$ & $1194.8^{\mathrm{bc}}$ & $1085.3^{\mathrm{d}}$ & $986.3^{\mathrm{f}}$ & 18.866 \\
\hline
\end{tabular}

Table (4): Effect of experimental diets on ruminal pH and ammonia concentrations.

\begin{tabular}{|c|c|c|c|c|c|c|c|c|c|c|c|}
\hline \multirow[t]{2}{*}{ Item } & \multirow[t]{2}{*}{ Control } & \multicolumn{3}{|c|}{ Crude olive cake } & \multicolumn{3}{|c|}{ Untreated olive cake silage } & \multicolumn{3}{|c|}{ Treated olive cake silage } & \multirow[b]{2}{*}{ \pm SEM } \\
\hline & & $\mathrm{T} 1$ & $\mathrm{~T} 2$ & $\mathrm{~T} 3$ & $\mathrm{~T} 4$ & $\mathrm{~T} 5$ & T6 & $\mathrm{T} 7$ & $\mathrm{~T} 8$ & T9 & \\
\hline $\mathrm{pH}$ & $7.04^{\mathrm{a}}$ & $6.98^{\mathrm{ab}}$ & $6.98^{\mathrm{ab}}$ & $6.98^{\mathrm{ab}}$ & $6.97^{\mathrm{ab}}$ & $6.93^{b}$ & $6.95^{\mathrm{b}}$ & $6.96^{\mathrm{b}}$ & $6.96^{\mathrm{b}}$ & $6.99^{\mathrm{ab}}$ & 0.007 \\
\hline $\mathrm{NH}_{3}$ & $32.31^{\mathrm{cd}}$ & $31.08^{\mathrm{d}}$ & $39.28^{\mathrm{ab}}$ & $32.49^{\mathrm{cd}}$ & $38.81^{\mathrm{abc}}$ & $34.40^{\mathrm{abcd}}$ & $33.66^{\text {bcd }}$ & $40.59^{\mathrm{a}}$ & $37.73^{\mathrm{abcd}}$ & $38.10^{\mathrm{abc}}$ & 0.766 \\
\hline
\end{tabular}

$a, b, c$ and $d$ means with different superscriptes in the same row are significant $(P<0.05)$.

Table (5): Effect of experimental diets on nutrients digestibility.

\begin{tabular}{|c|c|c|c|c|c|c|c|c|c|c|c|}
\hline \multirow[t]{2}{*}{ Item } & \multirow[t]{2}{*}{ Control } & \multicolumn{3}{|c|}{ Crude olive cake } & \multicolumn{3}{|c|}{ Untreated olive cake silage } & \multicolumn{3}{|c|}{ Treated olive cake silage } & \multirow[b]{2}{*}{$\pm \mathrm{SEM}$} \\
\hline & & $\mathrm{T} 1$ & $\mathrm{~T} 2$ & $\mathrm{~T} 3$ & $\mathrm{~T} 4$ & T5 & T6 & $\mathrm{T} 7$ & $\mathrm{~T} 8$ & T9 & \\
\hline DM digestibility & $51.28^{\mathrm{cd}}$ & $59.33^{\mathrm{ab}}$ & $52.95^{\mathrm{cd}}$ & $49.63^{\text {cd }}$ & $58.75^{\mathrm{ab}}$ & $54.53^{\mathrm{bc}}$ & $49.33^{\text {cd }}$ & $60.42^{\mathrm{a}}$ & $55.8^{\mathrm{b}}$ & $48.13^{\mathrm{d}}$ & 0.837 \\
\hline NDF digestibility & $33.28^{c}$ & $29.62^{\text {de }}$ & $34.02^{\mathrm{c}}$ & $38.80^{\mathrm{b}}$ & $28.93^{\mathrm{e}}$ & $34.02^{\mathrm{c}}$ & $39.17^{\mathrm{b}}$ & $28.25^{\mathrm{e}}$ & $32.08^{\mathrm{cd}}$ & $42.20^{\mathrm{a}}$ & 0.778 \\
\hline ADF digestibility & $23.58^{\mathrm{cd}}$ & $21.44^{\mathrm{de}}$ & $25.97^{\mathrm{bc}}$ & $28.62^{\mathrm{ab}}$ & $20.51^{\mathrm{e}}$ & $24.80^{\mathrm{c}}$ & $29.32^{\mathrm{a}}$ & $21.40^{\mathrm{de}}$ & $23.67^{\mathrm{cd}}$ & $30.98^{\mathrm{a}}$ & 0.623 \\
\hline
\end{tabular}

$a, b, c, d$ and e means with different superscriptes in the same row are significant $(P<0.05)$. 


\section{REFERENCES}

Abbeddou, S.; Rischkowsky, B.; Richter, E.K.; Hess, H.D. and Kreuzer, M. (2011). Modification of milk fatty acid composition by feeding forages and agro-industrial by-products from dry areas to Awassi sheep. J. Dairy Sci., 94, 4657-4668.

Abd El Tawab, A.M.; Khattab, M.S.A.; El-Zaiat, H.M.; Matloup, O.H. and Hassan, A.A. (2016). Effect of cellulase and tannase enzymes supplemention on the productive performance of lactating buffaloes fed diets contain date palm fronds. Asian J. Anim. Sci., 10: 307-312.

Abd El Tawab, A.M.; Matloup, O.H.; Kholif, A.M.; Abo El-Nor, S.A.H.; Murad, H.A.; El-Sayed, H.M. and Khorshed, M.M. (2015). Influence of Addition of Tannase Enzyme to Reducing Tannins Effects in Lactating Goats Diets. Int. J. of Dairy Sci., 10 (1): 24-35.

Al Jassim R.A.M; Awadeh F.T. and Abodabos A. (1997). Supplementary feeding value of urea-treated olive cake when fed to growing Awassi lambs. Anim. Feed Sci. Technol., 64:287-292.

Al-Masri M.R. and Guenther K.D. (1995). The effect of gamma irradiation on in vitro digestible energy of some agricultural residues. Wirtschaftseigene Futter. 41:61-68.

AOAC (1995). Official Methods of Analysis. Association of Analytical Chemists. 16th ed. Washington, D.C., USA.

Awawdeh M.S. and Obeidat B.S. (2011). Effect of supplemental exogenous enzymes on performance of finishing Awassi lambs fed olive cake-containing diets. Livest Sci., 138:20-24.

Awawdeh, M.S. and Obeidat B.S. (2013). Treated olive cake as a non-forage fiber source for growing Awassi lambs: effects on nutrient intake, rumen and urine $\mathrm{pH}$, performance and carcass yield. Asian Aust. J. Anim. Sci., 26:661-667

Bendaou M. (2003). Evaluation de la fermentescibilité de la matière organique dans le rumen par la méthode des seringues: cas des rations à base de fourrage d'avoine chez les ovins au Maroc. Diplôme des Etudes Approfondies en Sciences Agronomiques et Ingénierie Biologique. Faculté des Sciences Agronomiques de Gembloux, Belgique.

De Boever, J.L.; Aerts, J.M.; Vanacker J.M. and De Brabander D.L. (2005). Anim. Feed Sci. Technol., 255: 123-124.

Dong, Y.; Bae, H.D.; McAllister, T.A.; Mathison, G.W. and Cheng, K.J. (1999). Effects of exogenous fibrolytic enzymes, $\alpha$-bromoethanesulfonate and monensin on fermentation in a rumen simulation (RUSITEC) system. Can. J. Anim. Sci., 79:491.

Erdman R.A.; Proctor G.H.; van der Sall J.H. (1986). Effects of rumen ammonia concentration on in situ rate and extent of digestion of feedstuff, J. Dairy Sci., 69:2312-2320.

Feng, P.; Hunt, C.W.; Pritchard, G.T and Julien, W.E. (1996). Effect of enzyme preparations on in situ and in vitro degradation and in vivo digestive characteristics of mature cool-season grass forage in beef steers. J. Anim. Sci., 74:1349-1357.

Giraldo, L.A.; Ranilla, M.J.; Tejido, M.L. and Carro, M.D. (2004). Effects of cellulase application form on the in vitro rumen fermentation of tropical forages. J. Anim. Feed Sci., 13 (Suppl.1):63-66.

Hadjipanayiotou, M. (1994). Voluntary intake and performance of ruminant animals offered poultry litter-olive cake silage. Livest. Res. Rural. Dev., 6, 1-9.

Hadjipanayiotou, M. (1999). Feeding ensiled crude olive cake to lactating Chios ewes, Damascus goats and Friesian cows. Livest. Prod. Sci. 59, 61-66.

Karabulut, A.; Canbolat, O.; Ozkan, C.O. and Kamalak, A. (2007). Determination of Nutritive Value of Citrus Tree Leaves for Sheep Using In vitro Gas Production Technique. Asian-Aust. J. Anim. Sci., 20(4):529-535.

Khattab, M.S.A.; Abd El Tawab, A.M. and Fouad, M.T. (2017). Isolation and characterization of anaerobic bacteria from frozen rumen liquid and its potential characterizations. Int. J. Dairy Sci., 12: 47-51. 
Khattab, M.S.A.; Ebeid, H.M.; Abd El Tawab, A.M.; Abo El-Nor, S.A.H.; and Aboamer, A.A. (2016) Effect of supplementing diet with herbal plants on ruminal fiber digestibility and gas production. Res. J. of Pharm., Bio. and Chem. Sci., 7(6):1093-1097.

Kung, Jr. L. (2010). A review on Silage Additives and Enzymes. Department of Animal and Food Sciences University of Delaware Newark, DE 19717-1303.

Molina-Alcaide, E. and Nefzaoui A. (1996). Recycling of olive oil by-products: possibilities of utilization in animal nutrition. Int. Biodeterior Biodegrad. 38:227-235.

Molina-Alcaide, E. and Yáñez-Ruiz, D.R. (2008). Potential use of olive by-products in ruminant feeding: A review. Anim. Feed Sci. Technol., 147:247-264.

Muwalla, M.M.; Haddad, S.G. and Hijazeen, M.A. (2007). Effect of fibrolytic enzyme inclusion in high concentrate fattening diets on nutrient digestibility and growth performance of Awassi lambs. Livest. Sci., 111:255-236.

Ørskov, E.R. and Ryle, R. (1990). Energy Nutrition in Ruminants; Elsevier Science Publishers: New York.

Salihu, A., Abbas, O.; Sallau, A.B. and Zahangir Alam, M.d. (2015). Agricultural residues for cellulolytic enzyme production by Aspergillus niger: effects of pretreatment Biotechnology 5(6): 1101-1106.

Sujani, S. and Seresinhe, R.T. (2015). Exogenous Enzymes in Ruminant Nutrition: A Review Asian J. of Anim. Sci., 9 (3): 85-99.

Van Soest, P.J.; Robertson, J.B. and Lewis, B.A. (1991). Methods for dietary fiber, neutral detergent fiber, and non-starch polysaccharides in relation to animal nutrition. J. Dairy Sci., 74, 3583-3597.

تحسين الاستفادة من سيلاج تفل الزيتون المعامل بالانزيمات المحلله للالياف علي الهضم وانتاج الغاز بالكرش

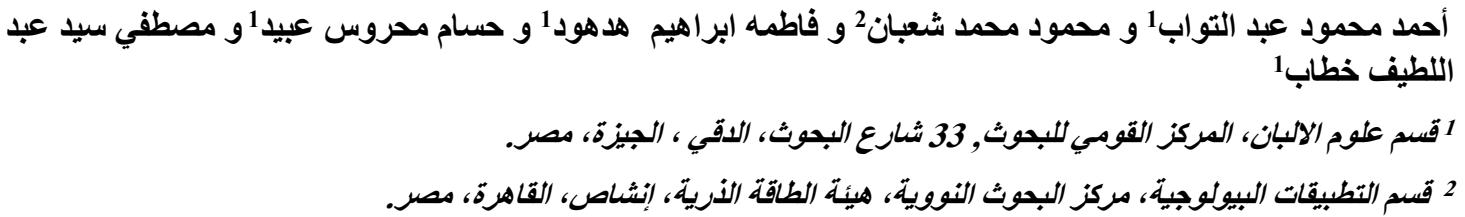

اجريت هذه التجربة بغرض دراسة تأثير استبدال دريس البرسيم بسيلاج تفل الزيتون المعامل او غير المعامل بالانزيمات المحللة

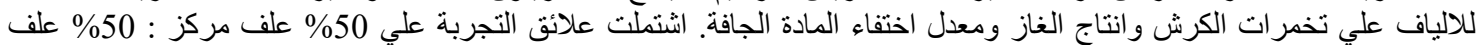

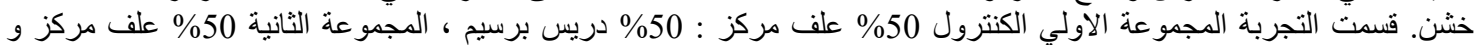

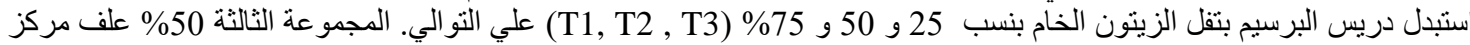

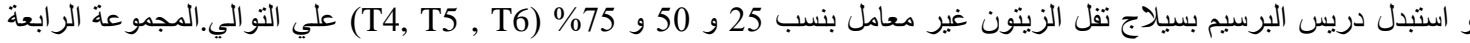

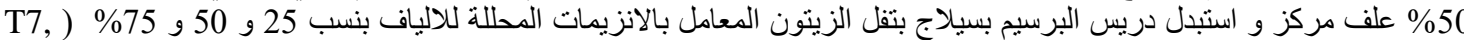
ع8 , T9

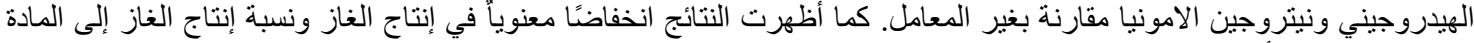

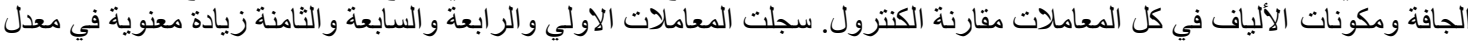
اختفاء المادة الجافة مقارنة بالمجمو عة الكنترول.

الخلاصة: نظهر النتائج الحالية ان هناك امكانية لاستبدال دريس البرسيم بسيلاج تفل الزيتون وخاصة المعامل بالانزيمات المحللة 